\title{
Milan Kundera and Franz Kafka- How Not to Forget Everydayness
}

Martin Škop

\section{Abstract}

Purpose of the article is to show that while in fundamental constitutional questions we are still attentive to our past, in everyday legal cases we can forget more likely. In my opinion, in case of the post-communist countries it is very dangerous to forget the Past because we have nothing other than our memories. To forget means either to be exposited the danger of return to the system as it was or to transform our legal praxis into a depersonalized system.

Methodology/Methods In this article I want to analyze two decisions of Constitutional Court of the Czech Republic and compare them with situation described in early works of Milan Kundera (The Joke; The Book of Laughter and Forgetting). His work reflecting the past everydayness in communist Czechoslovakia can be used as a good example of the analyses of forgetting. Very similar inspirations we can find in work of Franz Kafka (The Trial) or even better in Milan Kundera's interpretation of Kafka's work. The scientific aim of this article is to show that although the literature represents different conception of knowledge when this knowledge is compared with legal knowledge we can gain parallels that describe the law rooted in culture and society.

Conclusions of this article show that on one side we face reminding of our Past in decisions regarding politically considerable cases. On the other side we face the oblivion: In cases at constitutional level dealing with everydayness in legal praxis we can find rather shift to formal interpretation without any reference to our past. The result can be Kafkaesque legal system without any signs of living people.

Keywords: Law and Literature; Constitution; Legal Theory; Interpretation of Law; Sociology of Law

JEL Classification: K00, K40

\section{Using literature to describe the past of law}

A few words that Ludvik addressed to his girlfriend: „Optimism is the opium of the people! A healthy atmosphere stinks of stupidity! Long live Trotsky! Ludvik“ - who was at a training session on the strategy and tactics of the revolutionary movement - as an ironic joke meant a lot. Being expelled from university, having to find a job, a conflict 
with the admired party etc. Although in the end Ludvik found himself, it does not mean that his fate was not altered - those few words had a significant and unforgiving impact. Sending them pushed him to the cogwheels of a machinery, a machinery intended to maintain a system that was fast losing its legitimacy. A way of legitimating was to create stories whose real substance was completely transformed. Ludvik's clumsy joke became an attack on the socialist system.

The past demonstrates itself in law. Law is linked to the past as it requires a continuum. To approach law correctly we need continuity (as well as discontinuity). We need visible continuity also to maintain stories that we link to law and to compose stories with which we create law. Narratives that are spread about law can have a backing in the past, a story or a narrative can help maintain continuity. The French philosopher Jean Baudrillard argues: "We require a visible past, a visible continuum, a visible myth of origin, which reassures us about our end." (Baudrillard 1994, 10) The past - and that also in a legal system - enables us to trace the trajectory of movement. It can show us where we can get with the help of law. As Baudrillard says - the past serves our future. This does not only involve a symbolic dimension but also those of content and form. The symbolic dimension can demonstrate itself in the possibility of legitimating a legal order with the help of history. When exploring legitimate domination (authority), Max Weber identifies reasons for its legitimation, e.g. on traditional grounds: “... grounds resting on an established belief in the sanctity of immemorial traditions and the legitimacy of those exercising authority under them..." (Weber 1978, 215) Time tests legitimacy.

Content also links to the past. Interpretation frequently does not work only with the actual moment in which it is conducted but also refers to the past. The value associated with the content of a normative text stems not only from its author (from a story) but also from the context at the moment of the normative text's inception. Michel Foucault, for example, believes that with scientific discourse it is the author who guarantees integrity. He suggests that up until the $17^{\text {th }}$ century the scientific value of a work, its plausibility, stemmed from the author. (Foucault 1994, 16) The author is the one who carries prestige. (Barthes 1977, 142 - 143) It is a product of social premises and expectations - and that as in the past so in the present. The value that we associate with an author in the present and which we associate with his past, has a significant impact on the value of the content that we work with in the present.

In law, similarly as in literature, we can also find an originalistic approach to the text that is very closely linked to the past. We explore the intentions of the creator of a legal norm at the time of its creation. Hence we also analyse the historical context of the creation of a normative text. A frequent criticism of originalism (in law as well as literature) involves methodological difficulties (how to identify actually relevant topics for the then norm creator) and inadequacies in attempts to understand an author from a different social and cultural milieu (what was, is a different world). The arguments that this approach utilizes "face not only the problem of explaining why intentions of long-dead people from a different social world should influence us, but also, perhaps more importantly, the problem of extracting intentions from the collectivity of individuals and institutions necessary to give legal validity to the Constitution." (Levinson 1982, 379) These difficulties significantly undermine such a pious approach to a text. The rigorous attachment to the author's intentions is too constraining and so is the attachment to historical circumstances and conditions. It is very difficult to objectify the author's original intentions or indeed the context in which the normative text came into being. 
Fiction represents a useful tool when uncovering the past and exploring the possible context of a norm's creation. Although it does not detect exactly what was happening at the time a norm was established and neither does it uncover the exact circumstances of its reception, fiction nonetheless represents a visible continuum. It describes a past situation that could have been. It also enables us to comprehend how we saw the events subsequently and how we view them now. The already mentioned continuum forms part of literature that can help us understand realities that are important for the interpretation of the text of a legal norm.

Ludvik is suspended from the Communist Party, forced to quit his studies at university and make a living in ways that he has not been used to. All these consequences are perhaps really due to the postcard with the words that opened this paper. But this is possible only in the given historical context, otherwise it is frighteningly absurd. Can we without knowing the context - actually understand Ludvik's infantile joke?

\subsection{Franz Kafka}

In his literary fantasies Franz Kafka offers us a world that is perhaps not suited even for dreaming. Kafka's world is bizarre, fantastic, it is presented as reality without a trace of doubt. Robin West argues that it is tragic and full of irony. (West 1985, 387) After all, people living in it decide "freely" in a situation full of coercion. They are motivated by an unclear and confusing desire to succumb to authority, to its power. It is a romantic desire to succumb to something beautiful - Kafka depicts authority as noble while the subjugated subject demonstrates inadequacies.

We can argue that Kafka's works are texts that describe law and legal institutions (Minda 1995; West 1985; Litowitz 2002), possibly because Kafka himself happened to be a lawyer. Perhaps his specific sensibility enabled him to analyze everything as elements of some sort of a "process" - a legal or administrative process from which there is no escape and that is inherent to society to which one was “thrown”. In Kafka's rendering law demonstrates characteristics that - according to postmodern critique (Derrida 1991) - are inherent in modern law.

A literary work, however, is not a matter-of-fact and objective critique - unlike what is expected from a postmodern analysis of modern law - and indeed Kafka makes no such attempt. He is not concerned with a description of modern law or the modern world. Nonetheless, his texts can be seen as a metaphor of modern law, a metaphor that is in many moments absurd and imperfect. On the other hand, in its exaggeration and its stance beyond the limits of acceptability and "plausibility", it offers more space for a critique. The absurdity enables much greater detail that arises from a comparison of Kafka’s literary work with modern law. According to Milan Kundera, Gabriel García Márquez thinks alike: "I recall a conversation, by now twenty years back, with Gabriel García Márquez, who told me 'It was Kafka who showed me that it’s possible to write another way.' 'Another way' means: breaking through the plausibility barrier. Not in order to escape the real world (the way the Romantics did) but to apprehend it better." (Kundera 1996a, 52 - 53)

In terms of our topic, we can understand Kafka's fascination with authority as a special understanding of continuity or time. The depersonalization of law is reflected in the legend “Before the Law” not only in the doorkeeper's (Kafka 2009a, 153 - 155) rigidity and in the fascination of the officer (judge) who describes the punishment machine in the short story "In the Penal Colony" (Kafka 2009b, 75 - 99). The actual reason can be 
cultural differences within a society, it is only here - if we realize that a society is made up of a variety of communities, each of them working with time differently - that we can consider whether the convict understands why he is being punished and whether the punishment is not established long before he is aware of his guilt and the act itself. We walk on thin cultural studies ice here, law cannot exist in a way that would take account of all cultural difference. On the other hand, law cannot operate forgetting its own past this would bring about the danger of absolute emptiness.

\subsection{Milan Kundera}

This fascination with the system is also present in some of Milan Kundera's early work. The system is rigid, uniform and cold. In contrast to Franz Kafka's one, it is full of emotions and passions. It is its emptiness that makes it possible to charge it with negative passions and abuse the system for one's own needs and desires. An empty system has no in-built protection, no safety valve that would prevent the abuse of the system against an individual. A person thrown into the system can only follow how his words are interpreted, how the context is disregarded (the only issues taken into account are to his disadvantage). He only observes how he is uprooted from society and thrown back into it as an outsider - someone who does not belong there as he tried to harm it. This is how we could see Ludvik, whose words taken out of context set events into motions - events that were disagreeable. Yet these are consequences in the real world - not in Kafka's imaginary one.

Kundera - unlike Kafka - moves in the real world. He does not describe a system that could be imagined outside time and space (and that is only a continuum within a set of values) but rather a real system. The system that he describes is also the past of the Czech Republic, it depicts a system - including the legal one - that preceded the current understanding. One should perhaps mention that while Max Brod makes us forget the real Kafka (Kundera 1996a), according to Slavoj Zizek the Czech society forgets Kundera. "His works are rarely published, the media pass them over in silence, and everybody is somehow embarrassed to speak about him." (Zizek 1995, 929)

This paper deals with only two of Kundera's works - the above mentioned novel "The Joke" written while Kundera was still in Czechoslovakia and a collection of short stories "The Book of Laughter and Forgetting". The latter is apparently the first book that he wrote following his emigration. The former - "The Joke" - is a sad description of an inhumane system that is - despite all its cold and impersonal cruelty - created by people, people with their everyday situations and events. It is a mosaic that makes up the society and perhaps the whole world.

"The Book of Laughter and Forgetting" is interesting not only because it has "forgetting" in its title, but mainly because the first short story "Lost letters" not only describes a short episode in the life of an individual who is victimized by the system - just because he disagrees with it and that only because he insists on freedom of expression but because it very expressively describes what forgetting actually means. This is exemplified in the story with the hat that Vladimír Clementis lends to the communist tyrant Klement Gottwald during his most famous speech. The story about the hat that remains on Gottwald's head long after Clementis is executed and carefully removed from all the photographs hence leaving only the hat behind.

"The propaganda section made hundreds of thousands of copies of the photograph taken on the balcony where Gottwald, in a fur hat and surrounded by his comrades, 
spoke to the people. On that balcony the history of Communist Bohemia began. Every child knew that photograph, from seeing it on posters and in schoolbook and museums.

Four years later, Clementis was charged with treason and hanged. The propaganda section immediately made him vanish from history and, of course, from all photographs. Ever since, Gottwald has been alone on the balcony. Where Clementis stood, there is only the bare palace wall. Nothing remains of Clementis but the fur hat on Gottwald's head." (Kundera 1996b, 3 - 4)

However, nobody disappears completely - there are always traces left. It is only a question of not forgetting, of ways in which to interpret the traces. Law is tied to the continuum that determines the direction. It tells the story about why and how law was created and hence also a story about where it is going. A problem arises at the moment when we forget this story or when we try to alter it. This does not involve a situation when the story is only re-interpreted - although this is also a kind of change. A situation when a story is updated does not represent a problem either. A problem stems from a conscious falsification of the past such as the removal of Clementis from photographs - as if he never existed. Yet, the hat was left behind. Or a situation when we have illusions that are founded on nothing else but on further illusions.

A fate linked to a falsification of history and simultaneously the creation of illusions has - according to Kundera - also affected Franz Kafka whose life has been mystified by Max Brod. It was easy for Brod to forget Kafka's actual everyday life and mystify it. Kafka was no longer to be an ordinary human and writer, he had to become Saint Garta, a philosopher and a tragic hero. With Brod gradually erasing everydayness from Kafka's life and replacing it with eccentric details, he was constructing a completely new person. He constructed a completely new author of all the works. Hence he erased Franz Kafka from history and replaced him with someone who in fact probably did not live. Without everydayness Kafka ceased to exist and Brod's Kafka came into being.

\section{Everydayness and its meaning in law}

I assume that without everydayness there would be no law, it could not exist without ordinary lawsuits full of passion and desire. "We depend upon a hermeneutics of everydayness that makes us deeply historical. People in everyday life get on by using an unnoticed but extensive grid of tacit meanings about the world, its objects and institutions, and the acceptable forms of social behavior. These meanings have not been explicitly installed, nor are fully aware of their existence or function. We are socialized into them by imitation, usage and custom. In this sense, interpretation is the basic structure of experience. ... Interpretation is all that there is.” (Douzinas, Warrington, McVeigh 1991, 33) Doubtless, law as a system requires the symbolic dimension of grand lawsuits that reflect its uniqueness, authority and often also legitimacy. Yet, without everyday interventions, it would be impossible to use - law is a practice that has to resolve many everyday cases immediately.

If we forget what law is and what role it has in society, if we forget what a frightening tool it can be then we expose all those in contact with law to danger. And that danger without a corrective, as Terry Eagleton argues: "Franz Kafka's description of the law in The Trial has just the ambiguity of a necessity without justice. Like the Greek concept of dike, the law is logical but not equitable.” (Eagleton 2003, 130) Indeed, death exposed Kafka to the same danger, Kafka's death enabled the realization of Max Brod's idea to transform his life into that of a mystic, a philosopher, an ailing man and a dreamer who 
had bad experiences with women. Brod deformed Kafka to such an extent that Milan Kundera could not ignore it.

This paper deals with two decisions of the Constitutional Court. The decision Pl. ÚS 19/93 judges the constitutionality of the Act on the Lawlessness of the Communist Regime. I argue that this decision represents an example of uniqueness. It deals with a whole historical era and comes to terms with the law of the past that must be condemned by current law. It is a decision that establishes the existing legal system while it acknowledges the necessary formal link between the old and the new law. This decision does not want to forget, it does not want to forgive easily.

The other decision deals with litigation costs (ref. no. II. ÚS 549/06). It is an embodiment of pure everydayness, it involves a dispute that came into being "by mistake" yet it has a significant impact on the lives of all involved. It represents hundreds of disputes that are dealt with on a daily basis in various courts. On the other hand - and perhaps due to its everydayness - it is a decision that reminds us of forgetting. It is a decision that forgets what law is and what any law can turn into, a decision that becomes automatic, completely lacking a moral basis: "The morality that stands against the ineradicable human habit of judging instantly, ceaselessly, and everyone; of judging before, and in the absence of, understanding." (Kundera 1996a, 7) This decision is so formal that it lies completely outside of morality.

These two decisions are not representative, rather they are examples: examples of how forgetting can impact on law or how poignant this forgetting can be in everyday life. In addition, they also illustrate how important it is to remember in important cases.

\subsection{Decision regarding the Act on the Lawlessness of the Communist Regime and Resistance to It}

The first decision involves the lawlessness of the Communist regime and resistance to it. Above all, the act has a symbolic dimension, it states that the communist regime in Czechoslovakia was illegal and illegitimate and simultaneously legitimizes resistance to it. This act was opposed by a group of Communist members of parliament who submitted a constitutional complaint to the Constitutional Court with the aim of abolishing the act. The Constitutional Court rejected the complaint and - among others - stated: "Our new Constitution is not founded on neutrality with regard to values, it is not simply a mere demarcation of institutions and processes, rather it incorporates into its text also certain governing ideas, expressing the fundamental, inviolable values of a democratic society. The Czech Constitution accepts and respects the principle of legality as a part of the overall basic outline of a law-based state; positive law does not, however, bind it merely to formal legality, rather the interpretation and application of legal norms are subordinated to their substantive purpose, law is qualified by respect for the basic enacted values of a democratic society and also measures the application of legal norms by these values. This means that even while there is continuity of 'old laws' there is a discontinuity in values from the 'old regime'." (Pl. ÚS 19/93)

I think that in its decision the Constitutional Court is aware of the past. It knows it, it remembers it. It recalls a situation that existed before and attempts to differentiate it from the current situation. It creates the continuity of current law. The formal continuity of the old and the new law is maintained, yet due to the discontinuity in values, the two cases involve completely different law. The new law knows old law - the law of communist Czechoslovakia - and defines itself against it. 
The Constitutional Court cannot rectify the wrongdoings of the past - these cannot be undone. Yet it attempts to symbolically - in the name of the current system - apologize. It is not an actual apology or excuse - it is expressed in legal vocabulary and legal process, it attempts to act in a way that will make it impossible to understand the actions of those opposed to the Communist regime as a joke, as Kundera writes: "How happy I would be to revoke the whole story of my life! But what power have I to do so when the errors it stemmed from were not wholly my own? Who, in fact, made the error of arresting and sentencing Alexej's father (long since rehabilitated, but nonetheless dead)? So frequent, so common were those errors that they cannot be considered mere exceptions, 'aberrations' in the order of things; they were the order of things. And who made them? History itself? History the divine, the rational? And why call them history's errors? What if history plays jokes? And all at once I realized how powerless I was to revoke my own joke: I myself and my life as a whole had been involved in a joke much more vast (all-embracing) and absolutely irrevocable.” (Kundera 1982, 240)

\subsection{Everydayness}

I will now attempt a brief account of the second decision that I believe embodies everydayness, a decision that is representative of everyday disputes. Legal costs are the subject of a decision that was made by the Constitutional Court under ref. no. II. ÚS 549/06. The lawsuit involved a claim to expend "res mobiles". The things were lent for a total of seven years and the complainant (i.e. the party that turned to the Constitutional Court and lent the given things) requested their return as she believed that the rental contract was invalid. Hence she started a claim at a court of first instance. Overall the lawsuit went on for seven years and came to an end because the defendant (according to whom the contract was valid) returned the things after the rental period was over. Hence the court did not arrive at a meritorious decision as the subject of the lawsuit ceased to exist - the things were returned to the owner (the complainant). This part of the lawsuit was not the subject of the constitutional complaint. The problem was that the complainant was to pay the legal costs which exceeded 100.000 CZK (cca $4.200 €$ ). She launched her complaint because she thought that the lawsuit did not end due to her fault and hence she felt eligible to request an exemption from paying legal costs. However, the courts - and in the end the Constitutional Court as well - disagreed.

The Constitutional Court states in it decision that the dispute about the legal costs does not have an intensity that would impact on basic rights and freedoms - and that despite the fact that the impact can be strong. The Constitutional Court also reminds us that every democratic state is based on the principle according to which "rights and freedoms are linked to duties and that mainly the duty to face (potentially also unfavourable) consequences directly linked to the exercise of rights and freedoms." (II. ÚS 549/06). Does this really mean that if you get involved with law, you are to be punished? "Kafka's characters, if asked, would consent to impersonal state imperatives in order to satisfy an unquenchable thirst, not for wealth, but for judgment and ultimately for punishment." (West 1985, 416)

At this point I am not interested in exploring the legal elements of the dispute. I believe that it is more important that the decision is a typical representative of everydayness. It deals with disputes that are common and frequent in every legal system, disputes that do not reach the constitutional level, those that do not involve constitutional reflection. 
There is no doubt that the Constitutional Court guards its uniqueness among other courts. This could have been the motive for its action. At the same time, however, this also means that decisions that stem from dysfunctions in the system are unimportant for the Constitutional Court. They do not reach constitutional heights although such disputes represent an everyday component of law. And that more than disputes that involve the basis of a democratic lawful state and its fundamental principles. People get involved in disputes about legal costs more frequently that in those that involve Communist crimes.

This is not intended as disdain for dealing with Communist crimes. I completely respect their significance for the symbolic construction of law and for clearly defined continuity. Yet I am concerned whether the Constitutional Court in its withdrawal from the spaces of everydayness may leave these open to de-humanization. The withdrawal can mean that at the everyday level law becomes a machine that applies law regardless of the real nature of things - automatically. However, at this moment law is not an objective tool that expresses the rules of formal justice but rather a tool punishing anyone who wants to encounter law.

\section{The decisions in a literary context}

I think that the above mentioned two decisions stand in contrast. The first - dealing with the lawlessness of the Communist regime - creates the symbolic dimension of the impossibility to forget. It does not punish, it does not have the means to do so, yet it symbolically accuses and refuses to accept even an indication that the previous regime and the previous legal system were legitimate. It refuses to forget all the injustices that occurred in the past and it attempts to - at least partially - resolve the most serious wrongdoings. This decision (respectively the above mentioned act) made it possible to start lawsuits with those involved in the political trials of the 1950s, to judge the involvement of individual actors in political murders conducted on the stage of justice.

This decision of the Constitutional Court refuses to forget, it wants the opposite, in Milan Kundera's words: “... it would be forgotten with this table and the fly buzzing round my head and the yellow pollen scattered over the tablecloth by the flowering linden and the sluggish service so characteristic of the present state of the society I live in; and the society itself would consume me, that I'd vainly attempted to fix, right, rectify vainly, because whatever happened happened and could not be reversed.

Yes, suddenly I saw it all clearly: most people willingly deceive themselves with a double false faith; they believe in eternal memory (of men, things, deeds, peoples) and in rectification (of deeds, errors, sins, injustice). Both are sham. The truth lies at the opposite end of the scale: everything will be forgotten and nothing will be rectified. All rectification (both vengeance and forgiveness) will be taken over by oblivion. No one will rectify wrongs; all wrongs will be forgotten." (Kundera 1982, 245)

The decision of the Constitutional Court wants the whole legal system of a democratic state to carry the memory of an illegal regime that preceded it. It wants to prevent forgiving - it does not aim at punishing rather it is driven by not forgetting, in the Court's words: "In both cases, the differentiation of the levels of political and moral, and not of criminal, responsibility of individuals is concerned, and is characteristic of Parliament's initiative to reflect upon the past.” (ref. no. Pl. ÚS 19/93). 
The second decision is different, it came a decade later - a decade of forgetting. It is a decision that involves an everyday dispute. It is, needless to say, a decision that does not intend to renew the last regime, yet, in its content it can contribute to a depersonalization of law. The past is forgotten - or does not exist - all the same in this case. Hence a gap is created through which emptiness can enter the legal system that will be unable to stand up to a usurper's undemocratic fancy.

This case is indeed an example of pure everydayness. It represents a common case being dealt with every single day. It is exactly due to its commonness, banality and dullness that tiny fissures can occur - through these all values and elements that make up a democratic legal system disappear from law. It will be impossible to distinguish individual political systems as the same law will be valid in both - the form does not change. Only the key to our interpretation changes, the content. As if the past was forgotten in this decision, as if it were replaced with everydayness.

"The assassination of Allende quickly covered over the memory of the Russian invasion of Bohemia, the bloody massacre in Bangladesh caused Allende to be forgotten, the din war in the Sinai Desert drowned out the groans of Bangladesh, the massacres in Cambodia caused the Sinai be forgotten, and so on, and on and on, until everyone has completely forgotten everything." (Kundera 1996b, 9 - 10)

The ability to distinguish can be suppressed and hence space created for such law that Franz Kafka describes in the novel "The Trial".

The first discussed decision forms part of man's struggle against power, it is fitting to quote from Milan Kundera's “The Book of Laughter and Forgetting” here: "It is 1971, and Mirek says: The struggle of man against power is the struggle of memory against forgetting." (Kundera 1996b, 4) The second decision is perhaps rational and perhaps also in line with the formal expression of the legal system. Yet, it is empty. It forgets and refuses to see the evil that an emptied out system can cause. In this case the past looks like a caricature: "But of course it's true that the immediate circumstances which had made these tears real and believable baffled him now, and that the memory had become as implausible as a caricature." (Kundera 1996b, 6)

\section{The unbearable lightness of forgetting}

I believe that the above discussed two decisions of the Constitutional Court are linked to forgetting. The Czech legal system continues to come to terms with the inheritance of the past - with a legal system that attempted to be socialist yet it gradually became more and more of a rigid and formal system. (Kühn 2005) It worked increasingly more like a machine whose content cannot be identified and is expressed only in death. As in Kafka's short story "In the Penal Colony". It was a system with socialist rhetoric that did not support freedom or democracy but was actually in its real form very empty.

Nonetheless, the decisions are examples of forgetting, forgetting everydayness that emptiness linked to socialist law. (Kühn 2005) A loss of continuity, of the myth of origin, can come as a consequence (Baudrillard 1994, 10) and can open up a space not only for formal continuity but also continuity in content.

The Constitutional Court - in lawsuits that are significant for the state, the regime etc. - sides with memory at a symbolic level. It remembers the past and hence demonstrates its resolution to protect the current democratic and lawful state. To distinguish it from the past and thus legitimate it - legitimate for the present. Yet I think that the Court forgets 
about everydayness, a double act of forgetting - forgetting the every day and in this context also the dangerous emptiness of law. I believe that this act of forgetting opens up a space that is very dangerous for the society and the state and that can bring unwanted past elements into the system.

\section{References}

Barthes, R. (1977). Image Music Text. London: Fontana Press.

Baudrillard, J. (1994). Simulacra and Simulation. Ann Arbor: The University of Michigan Press.

Deleuze, G. Guattari, F. (2008). Anti-Oedipus. Capitalism and Schizophrenia. London: Continuum.

Deleuze, G. Guattari, F. (1986). Kafka: Toward a Minor Literature. University of Minnesota Press.

Derrida, J. (1991). Before the Law. In: Attridge, D. Acts of Literature. London: Routledge, pp. $181-220$.

Douzinas, C., Warrington, R., McVeigh, S. (1991). Postmodern Jurisprudence. The Law of Text in the Texts of Law. London: Routledge.

Eagleton, T. (2003). Sweet Violence. The Idea of the Tragic. Oxford: Blackwell Publishing.

Foucault, M. (1994). Diskurs Autor Genealogie. Tři studie. Praha: Svoboda.

Kafka, F. (1995). Stories 1904-1924. London: Abacus.

Kafka, F. (2009a). The Trial. Oxford: Oxford University Press.

Kafka, F. (2009b). The Metamorphosis and Other Stories. Oxford: Oxford University Press.

Kühn, Z. (2005). Aplikace práva soudcem v éře středoevropského komunismu a transformace. Praha: C. H. Beck.

Kundera, M. (1982). The Joke. London: Penguin Books.

Kundera, M. (1996a). Testaments Betrayed. New York: HarperCollins Publishers.

Kundera, M. (1996b). The Book of Laughter and Forgetting. New York: HarperCollins Publishers.

Levinson, S. (1982). Law as Literature. Texas Law Review, vol. 60, issue 3, pp. 373 - 404.

Litowitz, D. E. (2002). Franz Kafka's Outsider Jurisprudence. Law and Social Inquiry. vol. 27, issue 1, pp. $103-138$.

Minda, G. (1995). Postmodern Legal Movements: Law and Jurisprudence at Century's End. New York: New York University Press.

Weber, M. (1978). Economy and Society. University of California Press.,

West, R. (1985). Authority, Autonomy, and Choice: The Role of Consent in the Moral and Political Visions of Franz Kafka and Richard Posner. Harvard Law Review. vol. 99, issue. 2, pp. $384-428$.

Zizek, S. (1995). Superego by Deafult. Cardozo Law Review, vol. 16, pp. 925 - 942.

\section{JUDr. Mgr. Martin Škop, Ph.D.}

Department of legal theory, Faculty of Law, Masaryk University

Veveří 70, 611 80, Brno, Czech Republic

skop@law.muni.cz 